\title{
Information Management and Accountability for Multisectoral Nutrition Implementation in Burkina-Faso
}

\author{
Dieudonne Diasso ${ }^{1}$, Maimouna Halidou Doudou ${ }^{2}$, Florence Tonnoir ${ }^{3}$, Sarah Cruz $^{3}$, Aly Savadogo ${ }^{1,}$ * \\ ${ }^{1}$ Department of Biochemistry and Microbiology, University Joseph KI-ZERBO, Ouagadougou, Burkina-Faso \\ ${ }^{2}$ School of Public Health, Free University of Brussels (ULB), Brussels, Belgium \\ ${ }^{3}$ United Nations Network for the Scaling Up Nutrition Movement, World Food Programme (WFP), Rome, Italy
}

Email address:

clardiasso@yahoo.fr (D. Diasso), mhalidou2002@yahoo.fr (M. H. Doudou), florence.tonnoir@wfp.org (F. Tonnoir), sarah.cruz@wfp.org (S. Cruz), alysavadogo@gmail.com (A. Savadogo)

${ }^{*}$ Corresponding author

\section{To cite this article:}

Dieudonne Diasso, Maimouna Halidou Doudou, Florence Tonnoir, Sarah Cruz, Aly Savadogo. Information Management and Accountability for Multisectoral Nutrition Implementation in Burkina-Faso. Science Journal of Public Health. Vol. 8, No. 5, 2020, pp. $130-140$. doi: $10.11648 /$ j.sjph.20200805.11

Received: August 29, 2020; Accepted: September 16, 2020; Published: September 23, 2020

\begin{abstract}
The successful implementation of multisectoral operational plans in Burkina-Faso depends largely on the involvement and commitment of the technical departments from the key contributing sectors. The objective of this evaluation study is to analyze the capacities of the technical structures at the central level, and Regional Directorates level in the 13 regions of the country in terms of data management and accountability to identify gaps and challenges to the multisectoral process. The new Framework for Nutrition Capacity developed by the United Nations Network for Scaling Up Nutrition was used and adapted. Data collection and analysis consisted of triangulation of information: (1) literature reviews, (2) data collection and analysis from the evaluation guide and questionnaire and (3) observations. Cumulatively more than 20 technical departments, including those at the central and regional levels, did not have appropriate equipment or other means to record and monitor data. Among the thirty technical structures at the central level, only six had a nutrition focal point, and $47.3 \%$ (35out of the 74 ) had one. The existence of diverse kinds of data collected by different departments at all levels was observed, and a strong demand of information and data was expressed particularly at the level of the 13 regions of Burkina Faso. The lack of a functional national system on nutrition monitoring and evaluation to ensure accountability on the multisectoral approach at country level was noted. The needs and gaps identified, at different levels, among the key structures of the ministries involved in the multisectoral process, have made it possible to formulate strategic responses to better support the operationalization of the national nutrition policy.
\end{abstract}

Keywords: Capacity Assessment, Accountability, Nutrition, Regional Directions, Technical Structures, Central Level, Regional Level, Data Management

\section{Introduction}

Malnutrition is a universal problem that delays the physical and cognitive development of individuals and has unacceptable human consequences [1], although the conditions to end it seem more than ever reunited [2]. The United Nations (UN) Decade of Action for Nutrition (2016-2025) and the Sustainable Development Goals (2015-2030) call on the international community and individual countries to fight against malnutrition and accelerate progress [2]. Whether to transform global or national ambitions into concrete realities of reducing the prevalence of malnutrition, technical know-how and political commitment for sustainable mobilization of political systems, policy processes and resources at national and sub-national levels to improve nutrition [3-5] are required. In particular, coordination of actions within and across sectors (horizontal coordination) and at all levels of governance (vertical coordination) [6, 7], as well as knowledge and evidence management are required [3]. To accelerate progress, it is 
essential to set priorities and invest in the necessary data and the capacity to use it [1], because data gaps affect the ability to target resources, develop policy and monitor accountability $[6,8,9]$.

Effective interventions cannot be formulated without knowing the profile of those affected by malnutrition and its determinants. In the words of former UN Secretary-General Kofi Annan, "Data gaps undermine our ability to target resources, develop policy and monitor accountability. Without quality data, we are moving forward blindly. And we cannot solve what we don't see" [10].

Since 2014, Burkina-Faso has been engaged in a multisectoral planning process that mainly involves key ministerial departments. The national multisectoral nutrition plan (2020-2024) [11] is defined by five strategic objectives: (a) reduction of undernutrition, (b) reduction of micronutrient deficiencies, (c) strengthening the fight against overnutrition and chronic non-communicable diseases linked to nutrition, (d) strengthening food safety, (e) improving nutrition governance (see Figure 1, for the details of the last strategic objective). For the fifth one, The United Nations has called on States to strengthen "nutrition governance"; however, without going into the details of how to conduct this process, due to a lack of empirical evidence and a basis on which to issue recommendations [2, 12].

The objective of this assessment study is to analyze the capacities of public offices in terms of data management and accountability at central and regional levels and to identify the gaps and challenges for the successful operationalization of the national nutrition policy.

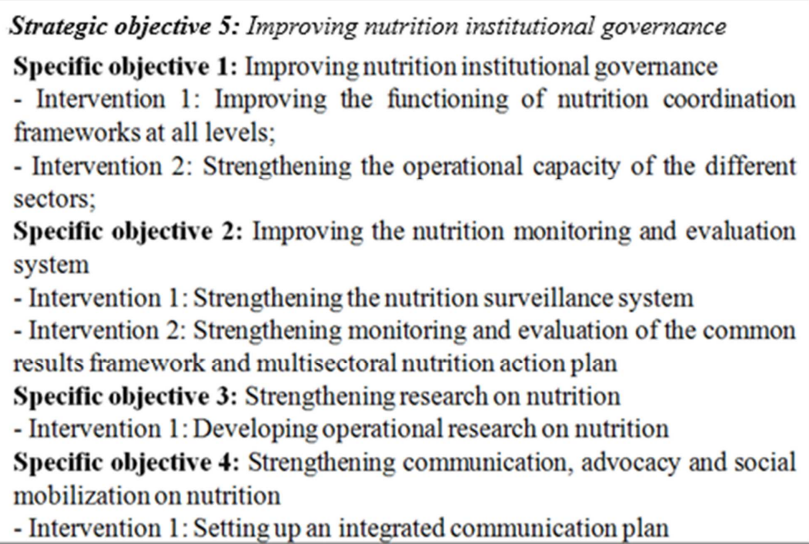

Figure 1. Strategic objective five of the national multisectoral nutrition plan. Source: Adapted from Ministry of Health [11].

\section{Methods}

This study is part of a broad need of assessments for nutrition capacity development, initiated in Burkina Faso, with a view to implement the nutrition strategic plan. This document is an evaluative cross study with descriptive and analytical aims conducted at the central and regional levels in the 13 regions of Burkina Faso. Data collection and analysis consisted in triangulation of information: documents reviews, data collection and analysis from evaluation surveys, and observations.

A multisectoral and multidisciplinary Technical Evaluation Committee (TEC), was put in place by the leadership of the Ministry of Health $(\mathrm{MoH})$, and it has supported the REACH Initiative (Renewed Efforts Against Child Hunger \& Undernutrition). This TEC was placed under the supervision of a group of "peer reviewers" composed of the four UN Nutrition Focal Points. The TEC implementation aimed to support and encourage the future use and appropriation of results [13-16], in a dynamic and complex environment [17] based on a collaboration $[18,19]$. The methods and tools proposed were useful to propose innovative strategies by facilitating thinking and decision-making [17, 20, 21]. One of the key actions of this study was real-time feedback to the sectors, and it was run through three phases (preparation, implementation, and synthesis of results and formulation of the capacity development plan) [18].

\subsection{Conceptual Framework of the Present Assessment}

The assessment process was guided by the Framework for Nutrition Capacity (Figure 2) [22], developed by the Secretariat of the United Nations Network/REACH. This framework provides two guides: (a) an orientation guide, and (b) a tool and resource kit. The framework highlights elements of capacity such as: (a) multisectoral capacities where the efforts of all sectors engaged in nutrition converge and align towards a common goal, (b) and sectoral capacities that are specific to the mission of each sector. Three dimensions of capacity (enabling environment, organizational and individual) cover multisectoral and sectoral capacities, and within each dimension, four areas of capacity (policies, programmes and frameworks, resources and infrastructure, coordination and partnerships, and evidence-based decision-making) can be developed. The framework, providing complementary tools and resources, is flexible and is adapted to different needs and specific contexts, taking into account the objectives of the assessments at country level.

The guides focus on government bodies that are instrumental in supporting nutrition scale-up at national and sub-national levels [22]. The package can also be used to assess the capacities of other stakeholders, as it recognizes the crucial roles played by them in nutrition governance. Some tools and methods were used to assess capacities: (a) stakeholder mapping [23], (b) a stakeholder analysis [23, 24], (c) the checklist for capacity areas tool [23], and (d) assessment guides. 


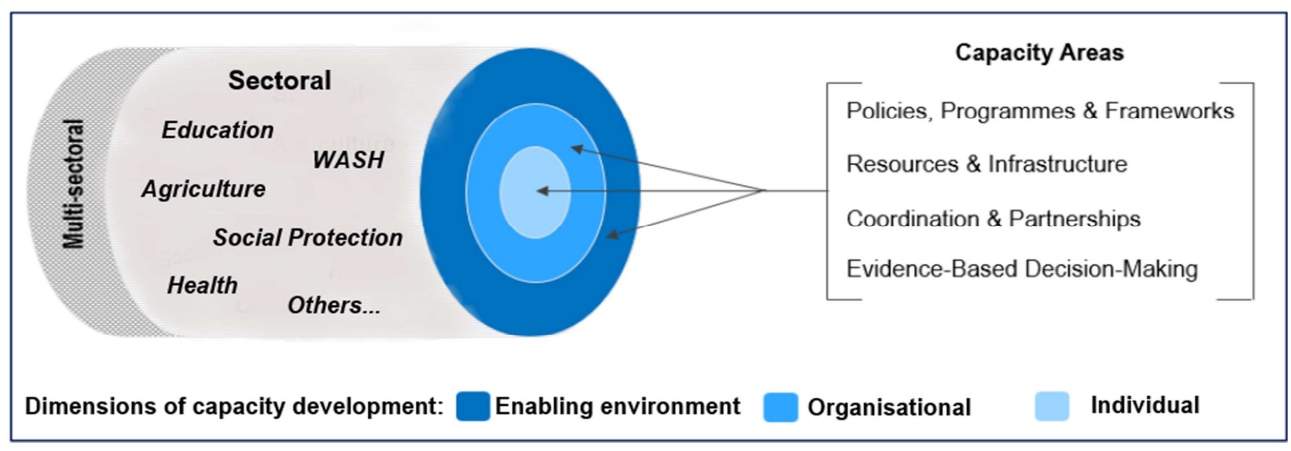

Figure 2. Framework for nutrition capacity. Source: Adapted from United Nations Network [22].

\subsection{Public Offices Identification and Selection}

The Technical Evaluation Committee members were trained to use the tool and resource kit for the various components of the analytical framework [22-24]. They contributed to the targeting and selection of participants that were included in this study. To identify and select institutions and structures, a series of tools and information collection methods were used successively: a Stakeholders Mapping and a Stakeholders Analysis.

The mapping made it possible to draw up a list of all key stakeholders (who does what, where and how?).

At the central level, technical structures involved in the common nutrition results were included. This list was complemented by the technical structures, organization charts and assignment use. At the regional level, the technical Regional Directorates (RD) of the key ministries were established. The stakeholder analysis examined the list of key institutions that derived from the mapping, according to their involvement in the implementation of the multisector nutrition plan, as well as their capacity to influence results [23, 24]. Institutions having both low resources/capacities to influence the results, and neutral interests in the multisectoral nutrition action plan, were finally not selected to be interviewed.

\subsection{Key Indicators Selected and Capacity Type Formulation}

The Checklist for Capacity Areas tool was used to establish the analytical framework [23], and from the capacity dimensions, a list of capacity areas and related assessment indicators (Table 1) was selected. To facilitate the objective and understanding of our study, the list of key indicators selected to assess needs in the table 1, are reorganized under five capacity types in table 2 only capacity types 5 is studied by this present paper; another paper will be related to the capacity number $1,2,3$, and 4 .

Table 1. Pre-analytical framework for nutrition capacity assessment.

\begin{tabular}{|c|c|c|}
\hline $\begin{array}{l}\text { Capacity } \\
\text { dimensions }\end{array}$ & Capacity Area & Key indicators selected to assess needs \\
\hline Individual & $\begin{array}{l}\text { Human Resources } \\
\text { and infrastructures }\end{array}$ & $\begin{array}{l}\text { Availability of certain profiles; Skills in advocacy, training, facilitation, mobilization of financial and material } \\
\text { resources, communication, and monitoring and evaluation; Technical expertise in monitoring and evaluation } \\
\text { Availability of work equipment, tools and internet connection; Suitable equipment to record data and monitoring }\end{array}$ \\
\hline \multirow{3}{*}{ Organisational } & $\begin{array}{l}\text { Resources and } \\
\text { Infrastructures }\end{array}$ & $\begin{array}{l}\text { Motivation of staff; Existence of a resource mobilization plan or strategy; Adequate skills to support the } \\
\text { expansion of nutrition services; Organizational difficulties: limiting internal factors; Existence of training plan } \\
\text { related to nutrition area; Adequate funding for data collection. }\end{array}$ \\
\hline & $\begin{array}{l}\text { Coordination and } \\
\text { partnership }\end{array}$ & Existence of an internal dialogue on nutrition; Organizational difficulties: limiting external factors \\
\hline & $\begin{array}{l}\text { Evidence-based } \\
\text { decision making }\end{array}$ & $\begin{array}{l}\text { Monitoring \& Evaluation Unit; Nutrition focal point; Diversity and type of data collected; Data and information } \\
\text { need; Functional mechanisms for knowledge-sharing }\end{array}$ \\
\hline \multirow{4}{*}{$\begin{array}{l}\text { Enabling } \\
\text { environment }\end{array}$} & $\begin{array}{l}\text { Policies, Programs } \\
\text { and Framework }\end{array}$ & Awareness and implementation of actions of the common results framework \\
\hline & $\begin{array}{l}\text { Resources and } \\
\text { Infrastructures }\end{array}$ & Financial difficulties \\
\hline & $\begin{array}{l}\text { Coordination and } \\
\text { partnership }\end{array}$ & Leadership and coordination of information; Collaboration with nutrition-related coordination bodies \\
\hline & $\begin{array}{l}\text { Evidence-based } \\
\text { decision making }\end{array}$ & Communication to stakeholders \\
\hline
\end{tabular}

Table 2. Adapted analytical framework for the study objective.

\begin{tabular}{ll}
\hline Type of capacity & Key indicators selected to assess needs \\
\hline 1) Human resource capacity & Motivation of staff; Availability of certain profiles; Availability of certain profiles; Adequate skills to support nutrition \\
and infrastructure & services expansion; Availability of work equipment, tools and internet connection \\
2) Functional capacity & Skills in advocacy, training, facilitation, mobilization of financial and material resources, communication, \\
3) Organizational capacity, & monitoring/evaluation \\
\hline
\end{tabular}




\begin{tabular}{cl}
\hline Type of capacity & Key indicators selected to assess needs \\
\hline coordination and partnership & $\begin{array}{l}\text { Awareness and implementation of actions of the common results framework; Existence of an operational work plan; } \\
\text { Organizational difficulties: limiting internal and external factors }\end{array}$ \\
$\begin{array}{c}\text { 4) Financial capacity and } \\
\text { resource mobilization }\end{array}$ & $\begin{array}{l}\text { Financial difficulties; Existence of a resource mobilization plan or strategy } \\
\text { Monitoring-evaluation package (technical expertise in monitoring and evaluation, suitable equipment to record data and } \\
\text { monitoring, monitoring and Evaluation unit); Information dissemination (functional mechanisms for knowledge-sharing, } \\
\text { communication to stakeholders); Nutrition focal point; Diversity and type of data collected; Data and information need; } \\
\text { 5) Data management capacity } \\
\text { and accountability }\end{array}$ \\
\hline
\end{tabular}

\subsection{Data Collection}

An evaluation guide, designed on the basis of key indicators selected to assess needs, reorganized and presented under five capacity types in table 2, was used for data collection at the central level. For the regional level a semi-structured questionnaire, designed and based on the semi-structured interviews' results, conducted previously at the central level, was used. The evaluation guides and the questionnaire were focused on five points: (a) general information about the organization, (b) human resources and infrastructure, (c) organizational analysis and functional capacity (d) information management and accountability system, and (e) financial resources.

Data collection at the central level took place between October 2017 and June 2018, and at the regional level it took place between November 2017 and July 2018 through interviews. Four focal points were mobilized for the central level, and three teams of two people were deployed in the 13 regions, with a distribution of approximately four regions per team. The questionnaires and the guide were pre-tested among the committee members (12 people) and the group of "peer reviewers" (5 people). Interviews were carried out with people organized in teams of 2 to 4 persons.

During our interview, note-taking was applied, and when information was missing or clarification needed the institution was contacted again. This option was preferred to audio recording, as the public employees that participated wanted the interviews to take place without a tape recorder. The veracity of the testimonies was tested by triangulation with other informants and documentation.

\subsection{Data Processing and Analysis}

For the qualitative data, both at the central and regional levels, a manual tabulation and content analysis were carried out. While for the regional level Excel software 2016 was used for data entry, quantifying, processing and testcrossing by SPSS Version 20. At all levels, an analysis matrix composed of the evaluation criteria, the existing situation and the desired situation made it possible to identify the gaps for nutrition capacity development.

Data results and information from the capacity type 5 proposed by the adapted analytical framework for the study objective, are presented as follow: (a) monitoring-evaluation package, (b) information dissemination, (c) existence of nutrition focal point, (d) diversity and type of data collected, (e) data and information need, (f) leadership and coordination of information.

\subsection{Ethical Considerations}

The study obtained approval from the institutional Ethics Committee of Centre Muraz. All the institutions were informed of the purpose of the study and provided verbal consent prior to starting interviews.

\section{Results}

\subsection{Presentation of the Participants}

At the central level, it involved the technical structures of nine key ministries engaged in the multisectoral approach to nutrition (primary education, health, agriculture, animal and fisheries, trade and industry, solidarity and the family, water and sanitation, research, and environment). Thus, a list of 30 key technical structures from the mapping (Tables 3 and 5) were examined and selected. At the regional level, the mapping involved the RD of the same nine ministries. Furthermore, from the stakeholder's analysis, the evaluation team produced a list of all the RD of the six key ministerial selected for the study: health, agriculture, animal and fisheries, primary education, water and sanitation, and solidarity and the family (Table 3 ).

\subsection{Monitoring-evaluation Package}

Both at the central and regional levels, almost all public offices reported having staff with experience in planning and coordination for data collection and monitoring. However, many of them mentioned that there are weaknesses in terms of capacity for data analysis.

\subsubsection{At the Central Level}

Almost all technical structures $86.2 \%(25 / 29)$ have a monitoring and evaluation unit or person. For the technical structures with a monitoring-evaluation (M\&E) service, the number of staff varies from 1 to 6 persons. The positions occupied by the persons directly in charge of $M \& E$ are distributed as follows: director (0/25), head of department $8 \%$ $(2 / 25)$, head of service $72 \%(18 / 25)$, simple agent $20 \%(5 / 25)$. They were mainly rural development engineers (water, agronomy, animal husbandry), educators and social service administrators, health officers and advisers, veterinarians, biologists, primary education advisers and inspectors.

Only $68 \%(17 / 25)$ M\&E cells or departments or persons had appropriate equipment or other means of recording and monitoring data. A researcher said:

"In our department, which has almost 50 people, there is no cell or person in charge of monitoring and evaluation. There 
is only one monitoring-evaluation unit serving all four departments under the Institute's management, with impacts on the department's activities on monitoring".

\subsubsection{At the Regional Level}

The results revealed that all the Regional Directorates have a department or person responsible for M\&E. The positions held by those directly responsible for M\&E were diverse (director $2.7 \%(2 / 73)$, head of department $1.4 \%(1 / 73)$, head of service $76.7 \%$ (56/73), head of section/head of office/ M\&E manager or officer $6.8 \%(5 / 73)$, or a simple agent $12.3 \%(9 / 73))$. In addition, their training profiles were diverse and varied from one region to another and from one regional management entity to another. The number of people dedicated to the M\&E service varied from 1 to 10 people, and nearly $85 \%$ of the services were composed of 1 to 4 people, more than $50 \%$ of whom had 2 or less staff. The directions that had appropriate equipment to record and monitor data $77 \%(57 / 74)$ were more numerous than those that did not have one $17.6 \%(13 / 74)$.

\subsection{Information Dissemination}

\subsubsection{At the Central Level}

We were able to note from the structures, that the most used functional mechanisms for knowledge sharing were the website $44.8 \%$ (13/29), newsletter $37.9 \%(11 / 29)$, reports $83 \%$ (24/29), and sharing workshops 76\% (22/29).

A sizeable proportion of structures (13/20 versus $7 / 20)$ report providing communication and feedback to stakeholders

from both "bottom up" and "top down". One agent commented on communication and feedback to stakeholders:

"This is mainly done through the review of sectoral dialogue frameworks, the involvement of stakeholders in national or communal workshops and through monitoring/drafting committees".

\subsubsection{At the Regional Level}

$67.6 \%$ of the Regional Directorates state that they communicate the reports to the stakeholders, and regarding the knowledge sharing mechanisms used by the Directorates, the dissemination of reports $(90.54 \%)$ and the holding of sharing workshops $(83.78 \%)$ come first, figure 3 . At the country level, information is shared on the websites of both the departments and respective partners, and also on the National Statistical Council website. However, most of the databases are not accessible online, except in rare cases such as the Integrated Management of Health Data «ENDOS» of the Ministry of Health, the Country Stat of the Ministry of Agriculture and Hydraulic Infrastructures.

Most of the data and information are centralized at the website of the National Institute of Statistics and Demography, where online platforms such as National data archives, Burkina Open data and BurkinInfo and the Afristat editorial platform are housed.

\subsection{Existence of Nutrition Focal Point}

\subsubsection{At the Central Level}

The results revealed that only 20.7 per cent $(6 / 29)$ of the technical departments have a nutrition focal point (DAMSSE, ABNORM, DGA, DN, DGESS of the Ministry of social action and DGESS of the Ministry of Education) against 79.3 per cent (23/29). These focal points, although designated by their home structure as part of the multisectoral process initiated since 2014 by the Ministry of Health, have not received an official letter of recognition. These 6 focal points occupy various positions within their institution, ranging from simple agent (3), head of service (2) to head of department (1).

\subsubsection{At Regional Level}

The analysis showed that only $47.3 \%(35 / 74)$ of the RD had a nutrition focal point versus $52.7 \%$ (39/74), and among the 35 $\mathrm{RD}$, the focal point was officially recognized in $80 \%$ of them, versus $20 \%$. The focal points (head of service $(36.4 \%$ ), head of section/head of office (18.2\%), single agent (45.5)) were of diverse profiles. It should be noted that there is a statistically significant relationship between the sector's Regional Directorates and having a nutrition-related focal point (Table 4). However, the focal points from the different sectors (education, agriculture and animal husbandry, social protection) are not linked to the Secretariat in charge of multisectoral nutrition coordination or to the Nutrition Directorate. Those in the health sector are also not under the responsibility of the Secretariat in charge of nutrition coordination, but are closely related to the Secretariat through the regional health directorates. In addition, it should be noted that the different type of focal points, are called differently from one sector to another: health, nutrition hygiene focal point for the RD of primary education, nutrition focal point for the RD of health.

Table 3. Distribution of key central technical structures and Regional Directorates involved in the interviews.

\begin{tabular}{llll}
\hline & \multicolumn{2}{c}{ Central level technical structures } & \multicolumn{2}{c}{ Regional Directorates } \\
\cline { 2 - 4 } Ministerial Departments & $\begin{array}{l}\text { Number of key technical } \\
\text { structures selected after } \\
\text { the stakeholder mapping }\end{array}$ & $\begin{array}{l}\text { Total number of } \\
\text { interviewed } \\
\text { technical structures }\end{array}$ & $\begin{array}{l}\text { Number of identified } \\
\text { RD and selected after } \\
\text { stakeholder analysis }\end{array}$ \\
$\begin{array}{llll}\text { Number of RD } \\
\text { interviewed }\end{array}$ & 3 & 13 \\
Ministry of National Education and Literacy & 3 & 5 & 13 \\
Ministry of Health & 6 & 6 & 13 \\
Ministry of Agriculture and Hydraulic arrangement & 6 & 3 & 13 \\
Ministry of Animal and Fisheries Resources & 3 & 3 & 13 \\
Ministry of Women, National Solidarity and the Family & 3 & 4 & 13 \\
Ministry of water and sanitation & 4 & 1 & 13 \\
Ministry of Trade, Industry and Handicrafts & 1 & 3 & 13 \\
Ministry of Higher Education, Scientific Research and & 3 & 0 & 0 \\
\hline
\end{tabular}




\begin{tabular}{|c|c|c|c|c|}
\hline \multirow[b]{2}{*}{ Ministerial Departments } & \multicolumn{2}{|c|}{ Central level technical structures } & \multicolumn{2}{|l|}{ Regional Directorates } \\
\hline & $\begin{array}{l}\text { Number of key technical } \\
\text { structures selected after } \\
\text { the stakeholder mapping }\end{array}$ & $\begin{array}{l}\text { Total number of } \\
\text { interviewed } \\
\text { technical structures }\end{array}$ & $\begin{array}{l}\text { Number of identified } \\
\text { RD and selected after } \\
\text { stakeholder analysis }\end{array}$ & $\begin{array}{l}\text { Number of RD } \\
\text { interviewed }\end{array}$ \\
\hline \multicolumn{5}{|l|}{ Innovation } \\
\hline $\begin{array}{l}\text { Ministry of Environment, Green Economy and } \\
\text { Climate Change }\end{array}$ & 1 & 1 & 0 & 0 \\
\hline Total $(\%)$ & $30(100 \%)$ & $29(96,66 \%)$ & $78(100 \%)$ & $74(94,87 \%)$ \\
\hline
\end{tabular}

\subsection{Diversity and Type of Data Collected}

In order to find out more about who collects what type of data, the departments were asked whether their data collection system takes into account data on nutrition, food security, health, social protection, education and water, hygiene and sanitation (WASH) among others.

\subsubsection{At the Central Level}

The analysis of table 5 indicates that the nature of the data collected by the departments is as follows: nutrition $34.5 \%$ (10/29), food security $65.5 \%(19 / 29)$, health $41.4 \%(12 / 29)$, social protection $34.5 \%(10 / 29)$, education $31 \%(9 / 29)$, WASH $48.3 \%(14 / 29)$ and gender $3.5 \%$ (1/29). Focusing on the data collected, diversity or plurality of the typologies, the Ministry of Education and those of National Solidarity and the Family and Research collect from 4 to 6 typologies.

\subsubsection{At the Regional Level}

Table 6 shows the predominance of the data most frequently collected by the Directorates. Data on food security, health and water, hygiene and sanitation are the most collected by the different sectors. The analyses indicated that there were statistical relationships between the sectors and the collection of data on nutrition, food security, health, social protection, education and WASH $(p=0,000)$. The $\mathrm{RD}$ of health, agriculture, education, national solidarity collect most of the data on nutrition. In addition, it should be noted that the health data collected by the RD of animal and fisheries resources are related to animal health.

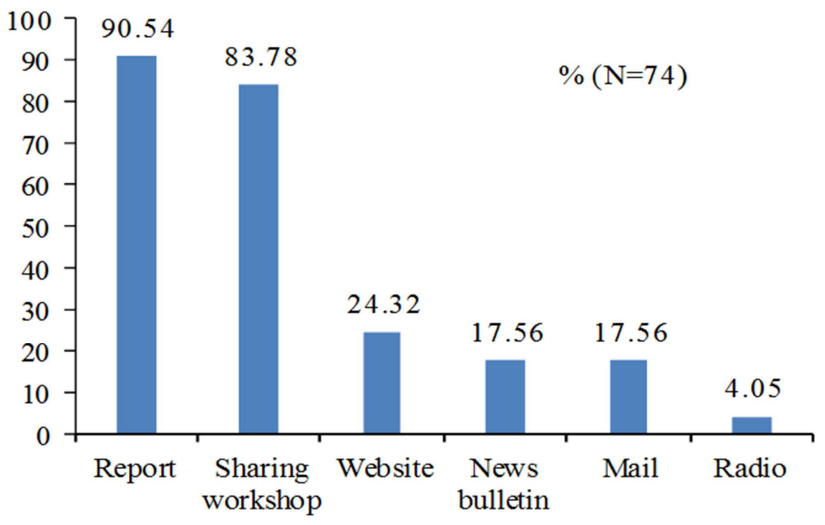

Figure 3. Functional knowledge-sharing mechanisms.

\subsection{Data and Information Need}

Beyond the data collected by the different departments, we wanted to capture more information about health, food security, nutrition, information and data that they need for decision-making processes and orientation of their activities.

At the central and regional levels, the most expressed needs in information were as follows: (i) the local food component and their nutritional value; (ii) the cereal balance sheet by district and cereal fluctuations; (iii) the mapping of food insecurity areas; (iv) the geological map (field geology); (v) the water quality report, availability and access to potable water by population; (vi) the evolution of malnutrition prevalence and its disaggregation; (vii) and the situation of water diseases.

Table 4. Relationship between the existence of focal points and key sectors.

\begin{tabular}{|c|c|c|c|c|}
\hline & \multicolumn{4}{|c|}{ Is there a focal point in a nutrition area within the Regional Directorates $?(p=0,000)$} \\
\hline & & Yes & No & Total \\
\hline \multirow{6}{*}{ Sector } & Regional Directorates of Health & 13 & 0 & 13 \\
\hline & Regional Directorates of Agriculture and Hydraulic Arrangement & 3 & 9 & 12 \\
\hline & Regional Directorates of Water and Sanitation & 0 & 11 & 11 \\
\hline & Regional Directorates of National Education and Literacy & 11 & 1 & 12 \\
\hline & Regional Directorates of Animal and Fisheries Resources & 4 & 9 & 13 \\
\hline & Regional Directorates of Women, National Solidarity and the Family & 4 & 9 & 13 \\
\hline
\end{tabular}

Table 5. Diversities and typologies of collected data at central level.

\begin{tabular}{|c|c|c|c|c|c|c|c|c|}
\hline \multirow{2}{*}{ Ministries } & \multirow{2}{*}{ Structures } & \multicolumn{7}{|c|}{ Typologies of collected data } \\
\hline & & Nutrition & Food security & Health & Social protection & Education & WASH & Gender \\
\hline \multirow{6}{*}{$\begin{array}{l}\text { Ministry of Agriculture and } \\
\text { Hydraulic Arrangement }\end{array}$} & SONAGESS & & $\sqrt{ }$ & \multirow{6}{*}{\multicolumn{2}{|c|}{ 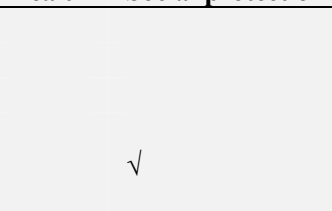 }} & & & \\
\hline & DPVC & & $\sqrt{ }$ & & & & \multirow{5}{*}{$\begin{array}{l}\sqrt{ } \\
\sqrt{ }\end{array}$} & \\
\hline & DDA/DGPER & & $\sqrt{ }$ & & & & & \\
\hline & SP/CPSA & & $\sqrt{ }$ & & & & & \\
\hline & DGESS & $\sqrt{ }$ & $\sqrt{ }$ & & & $\sqrt{ }$ & & \\
\hline & DTAN & $\sqrt{ }$ & $\sqrt{ }$ & & & $\sqrt{ }$ & & \\
\hline
\end{tabular}




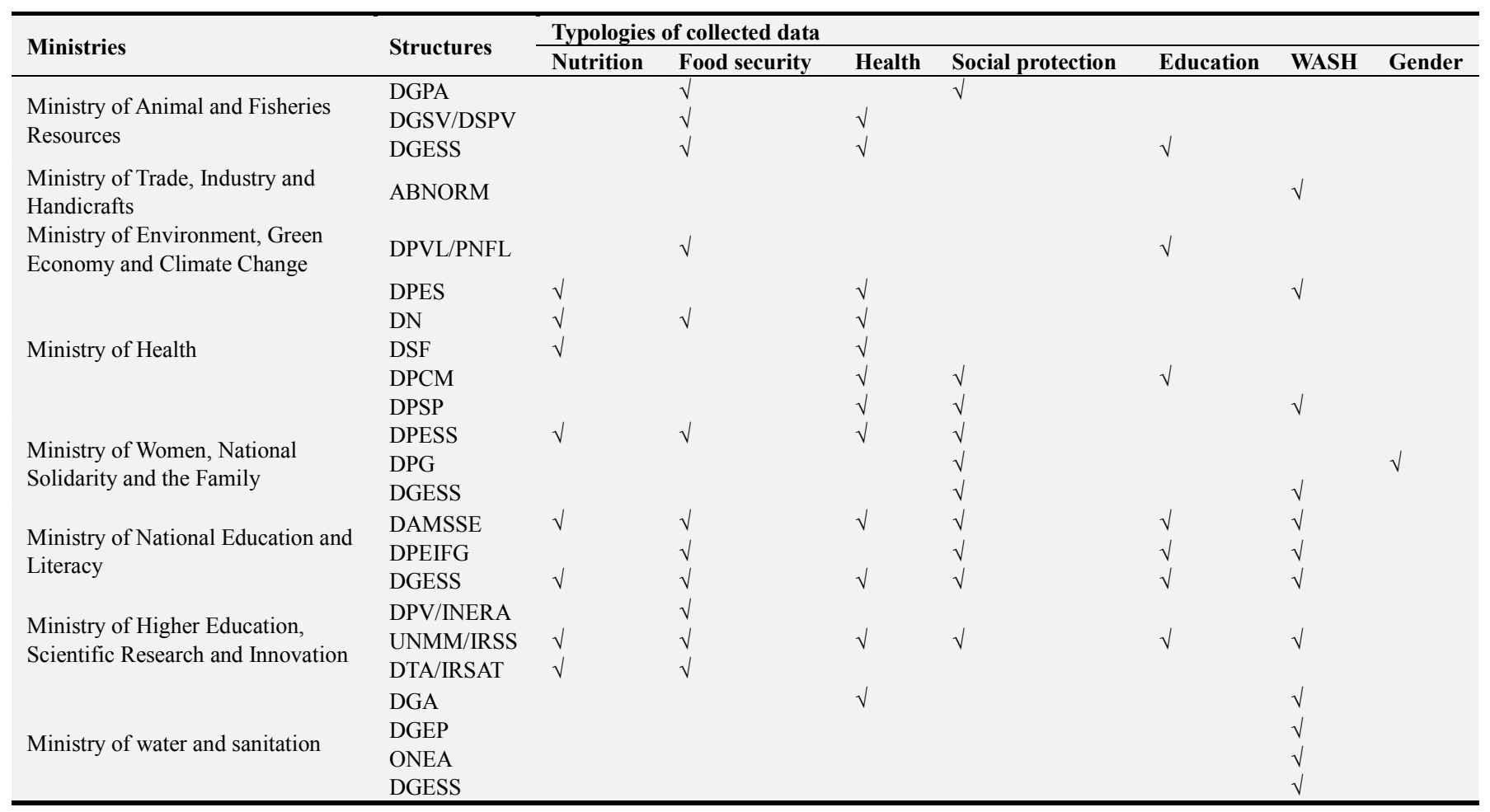

\section{$\sqrt{ }=$ Collected data}

Abbreviation: ABNORM, Burkina Faso Agency for Standardization, Metrology and Quality; DAMSSE, Directorate for the Allocation of Specific Means to Schools; DDEA, Directorate of Agricultural Entrepreneurship Development; DGA, General Directorate of Sanitation; DGEP, General Directorate for Potable water; DGESS, General Directorate for Sectoral Studies and Statistics; DGPA, General Directorate of Animal Production; DN, Nutrition Directorate; DPCM, Directorate of Non-Communicable Diseases Prevention and Control; DPES, Directorate of Health Promotion and Education; DPESSS, Directorate of Promotion for Social Education and Social Services; DPG, Directorate for Gender Promotion; DPEIFG, Directorate of Promotion for Inclusive Education, Girls and Gender; DPSP, Directorate for Health and Population Protection; DPV-PFNL, Directorate of Promotion and Valorization for Non-Timber Forest Products; DPV/INERA, Plant Production Department/Environmental and Agricultural Research Institute; DPVC, Directorate for Plant and Consumer Protection; DSF, Directorate for Health and Family; DSPVL, Directorate of Veterinary Public Health and Legislation; DTA/IRSAT, Department of Food Technology / Applied Science and Technology Research Institute; DTAN, Directorate of Processing, Food, Nutrition, and the Promotion of Standards and Agricultural Products Quality; ONEA, Water and Sanitation National Office; SONAGESS, National Society for Food Security Stock Management; SP-CPSA, Permanent Secretariat for Sectoral Agricultural Policies Coordination; UNMM/IRSS, Nutrition and Metabolic Diseases Unit/Department of Biomedicine and Public Health / Health Science Research Institute.

Table 6. Diversities and typologies of data collected at the regional level.

\begin{tabular}{|c|c|c|c|c|c|c|c|c|}
\hline \multirow[b]{2}{*}{$\begin{array}{l}\text { Regional Directorates of } \\
\text { Key Ministries }\end{array}$} & \multirow{2}{*}{$\begin{array}{l}\text { RD number/ } \\
\text { Regions } \\
\text { number }\end{array}$} & \multicolumn{7}{|c|}{ Typologies of collected data } \\
\hline & & & Nutrition & $\begin{array}{l}\text { Food } \\
\text { security }\end{array}$ & Health & Social protection & Education & WASH \\
\hline \multirow{2}{*}{ RD of Health } & \multirow{2}{*}{$13 / 13$} & Collected & $13 / 13$ & $1 / 13$ & $12 / 13$ & $0 / 13$ & $0 / 13$ & $4 / 13$ \\
\hline & & Uncollected & $0 / 13$ & $12 / 13$ & $0 / 13$ & $13 / 13$ & $13 / 13$ & 9/13 \\
\hline \multirow{2}{*}{$\begin{array}{l}\text { RD of Agriculture and } \\
\text { Hydraulic Arrangement }\end{array}$} & \multirow{2}{*}{$12 / 13$} & Collected & $3 / 11$ & $11 / 11$ & $2 / 11$ & $3 / 11$ & $0 / 11$ & $0 / 11$ \\
\hline & & Uncollected & $8 / 11$ & $0 / 11$ & $9 / 11$ & $8 / 11$ & $11 / 11$ & $11 / 11$ \\
\hline \multirow{2}{*}{ RD of Water and Sanitation } & \multirow{2}{*}{$11 / 13$} & Collected & $0 / 11$ & $0 / 11$ & $1 / 11$ & $1 / 11$ & $0 / 11$ & $11 / 11$ \\
\hline & & Uncollected & $11 / 11$ & $11 / 11$ & $10 / 11$ & $10 / 11$ & $11 / 11$ & $0 / 11$ \\
\hline \multirow{6}{*}{$\begin{array}{l}\text { RD of National Education } \\
\text { and Literacy } \\
\text { RD of Animal and } \\
\text { Fisheries Resources } \\
\text { RD of Women, National } \\
\text { Solidarity and the Family }\end{array}$} & \multirow{2}{*}{$12 / 13$} & Collected & $8 / 11$ & $10 / 12$ & $7 / 11$ & $7 / 12$ & $12 / 12$ & $12 / 12$ \\
\hline & & Uncollected & $3 / 11$ & $2 / 12$ & $4 / 11$ & $5 / 12$ & $0 / 12$ & $0 / 12$ \\
\hline & \multirow{2}{*}{$13 / 13$} & Collected & $0 / 13$ & $13 / 13$ & $11 / 13$ & $4 / 12$ & $2 / 13$ & $1 / 13$ \\
\hline & & Uncollected & $13 / 13$ & $0 / 13$ & $2 / 13$ & $8 / 12$ & $11 / 13$ & $12 / 13$ \\
\hline & \multirow{2}{*}{$13 / 13$} & Collected & $3 / 13$ & $7 / 12$ & $4 / 12$ & $13 / 13$ & $7 / 12$ & $4 / 12$ \\
\hline & & Uncollected & $10 / 13$ & $5 / 12$ & $8 / 12$ & $0 / 13$ & $5 / 12$ & $8 / 12$ \\
\hline
\end{tabular}

Table 7 lists and summarizes the thirty-four (34) main requests or needs for information collected during our survey (the vast majority being expressed by the $74 \mathrm{RD}$ ). A reaction from a Regional Directorate of Education on this subject:

"The indicators that we collect at the level of our region are among others on: the school canteens, number of schoolchildren, the existence of school gardens, the presence of water supply points and functional latrines. However, we lack data or information on the nutritional status and also the health of schoolchildren for example dental health."

\subsection{Leadership and Coordination of Information}

The level of commitment that a government has in producing 
representative, comprehensive and accessible data contributes to the development and implementation of effective nutrition policies, strategies, plans and programmes. A wide range of information systems or collection frameworks is available from key ministerial departments (economy and finance, health, agriculture, animal and fisheries, water and sanitation, research, environment, education). Each of these departments has its own coordination bodies for data collection, processing, and dissemination of information. Thus, there is a lack of coordination and the non-existence of a national statistical system on nutrition, which sometimes results with data sources redundant, fragmented, or even discordant from a methodological point of view. Of course, collaborations or links exist and allow the participation of resource persons from the technical service of other ministerial departments, Non-governmental organizations (NGO) and United Nations Agencies. This is the case for processes of certain collection frameworks for instance the National Nutrition Survey (ENN) of the Ministry of Health and the harmonized framework for food security and nutrition of the Ministry of Agriculture.

Discussions with certain stakeholders (UN and NGO) revealed that the government does not adequately take into account the recommendations resulting from the ENN surveys. Moreover, for example, during the developing process of a single national register of vulnerable people in which we participated, a certain leadership and consensus on the criteria and methods for choosing targets had been noted between social protection and food security actors. It was difficult to find a consensus on the notion of who is vulnerable; who is indigent person identified like vulnerable, unable to work and create wealth, compared to a farmer or herder who is vulnerable but able to be productive. Which category should be part of a scaling up of interventions to improve the food security of the population as a whole and fight poverty?

\subsection{Needs and Opportunities Identified}

About the findings from our study, a number of needs or actions have been identified to improve the information management and accountability for multisectoral nutrition planning (Table 8).

\section{Discussion}

Our study has attempted to address the state of monitoring and evaluation, data management, and the challenges of collection frameworks coordination, as well as the types of surveys and surveillance systems that are used to provide a comprehensive picture of the nutrition situation. While the collecting reliable data is crucial, so is its management, analysis and dissemination [25]. The analysis revealed that a sizeable proportion of departments reported providing communication and feedback to stakeholders. A study conducted by Patrick Webb in Nepal, showed that the sharing of nutrition information between different sectors would remain too limited [26]. Also, it was highlighted that data dissemination is most often done through the publication of survey reports, statistical yearbooks, dashboards and statistical bulletins. However, the level of maintenance of these web portals does not follow the evolving content. The data collected on indicators, their monitoring or analysis is most often done officially with the generating ministerial departments. Moreover, the persons directly in charge of M\&E matters were mostly heads of department or simple agents, with diverse training profiles.

Table 7. Data needs expressed by the public offices.

\begin{tabular}{|c|c|c|c|}
\hline Report type & Who must produce this report? & Report type & $\begin{array}{l}\text { Who must produce this } \\
\text { report? }\end{array}$ \\
\hline $\begin{array}{l}\text { Types of traditional food, their } \\
\text { composition and nutritional value }\end{array}$ & $\begin{array}{l}\text { Ministries of Agriculture, Trade, } \\
\text { Environment, and Research }\end{array}$ & Intensity of pesticide use & Ministry of Agriculture \\
\hline $\begin{array}{l}\text { Non-Timber Forest Products and their } \\
\text { nutritional Values }\end{array}$ & $\begin{array}{l}\text { Ministries of Agriculture, } \\
\text { Environment, and Research }\end{array}$ & Fertilizer tonnage & Ministry of Agriculture \\
\hline $\begin{array}{l}\text { Typology of food and their nutritional } \\
\text { values }\end{array}$ & $\begin{array}{l}\text { Ministries of Agriculture, Research, } \\
\text { and Health }\end{array}$ & Food, food security report & $\begin{array}{l}\text { Ministries of Agriculture, } \\
\text { Animal and Fisheries, and } \\
\text { Trade }\end{array}$ \\
\hline Children's milk consumption & $\begin{array}{l}\text { Ministry of Ministry of Animal and } \\
\text { Fisheries, and Health }\end{array}$ & Family Planning & Ministry of Health \\
\hline $\begin{array}{l}\text { Information on the food quality and } \\
\text { agricultural products }\end{array}$ & $\begin{array}{l}\text { Ministries of Agriculture, Trade, } \\
\text { Health; CILSS, FAO }\end{array}$ & $\begin{array}{l}\text { Status of iodine and anaemia in Burkina } \\
\text { Faso report }\end{array}$ & Ministry of Health \\
\hline Health Statistical Yearbook & Ministry of Health & Minors in conflict with law report & $\begin{array}{l}\text { Ministries of Labour and } \\
\text { Justice }\end{array}$ \\
\hline Education Statistical Yearbook & Ministry of Education & $\begin{array}{l}\text { Water quality, availability and access to } \\
\text { potable water by population report }\end{array}$ & $\begin{array}{l}\text { Ministry of Water and } \\
\text { Sanitation }\end{array}$ \\
\hline Livestock Statistics Yearbook & Ministry of Animal and Fisheries & $\begin{array}{l}\text { Epidemiological and vaccination (animal) } \\
\text { situation }\end{array}$ & $\begin{array}{l}\text { Ministry of Animal and } \\
\text { Fisheries }\end{array}$ \\
\hline $\begin{array}{l}\text { Water, Hygiene and Sanitation } \\
\text { statistical yearbook }\end{array}$ & Ministry of Water and Sanitation & $\begin{array}{l}\text { Information on children's food and } \\
\text { nutrition }\end{array}$ & Ministry of Education \\
\hline Agriculture Statistical Yearbook & Ministry of Agriculture & Schoolchild 's health status & Ministry of Education \\
\hline $\begin{array}{l}\text { National Statistical Yearbook (social } \\
\text { action) }\end{array}$ & Ministry of National Solidarity & $\begin{array}{l}\text { Education association and } \mathrm{NGO} \\
\text { repertoire }\end{array}$ & Ministry of Education \\
\hline $\begin{array}{l}\text { Cereal balance sheet by locality, by } \\
\text { municipalities and cereal fluctuations }\end{array}$ & Ministry of Agriculture & Schooling rate & Ministry of Education \\
\hline
\end{tabular}




\begin{tabular}{|c|c|c|c|}
\hline Report type & Who must produce this report? & Report type & $\begin{array}{l}\text { Who must produce this } \\
\text { report? }\end{array}$ \\
\hline Region Monograph & Ministry of Economy, and Governorate & Information on agricultural forecasts & Ministry of Agriculture; FAO \\
\hline Data on price policy (animals) & $\begin{array}{l}\text { Ministry of Ministry of Animal and } \\
\text { Fisheries }\end{array}$ & Social security (vulnerable group) & Ministry of National Solidarity \\
\hline Local economy & $\begin{array}{l}\text { Ministry of Economy and Finance, } \\
\text { Agriculture, Animal and Fisheries, } \\
\text { Environment, Research }\end{array}$ & $\begin{array}{l}\text { Information on future development zone } \\
\text { (drawing) }\end{array}$ & $\begin{array}{l}\text { Ministry of Economy and } \\
\text { Finance }\end{array}$ \\
\hline Social Surveys Report & Ministry of National Solidarity & $\begin{array}{l}\text { Potential development area (farming } \\
\text { coverage, irrigated areas situation) }\end{array}$ & Ministry of Agriculture \\
\hline Mapping of food insecurity areas & WFP; Ministry of Agriculture & $\begin{array}{l}\text { Prevalence of diarrheal diseases } \\
\text { (hydraulic and waterworks impacts) }\end{array}$ & Ministry of Health \\
\hline
\end{tabular}

Abbreviation: WFP, Word Food Programme; FAO, Food and Agriculture Organization; CILSS, Permanent Interstate Committee for Drought Control in the Sahel; NGO: Non-Governmental Organization.

Table 8. Identification of needs and actions to be undertaken.

\begin{tabular}{|c|c|c|}
\hline Summary of findings & Actions to be undertaken & Opportunities \\
\hline $\begin{array}{l}\text { Weak institutionalization of nutrition at the } \\
\text { level of sectoral ministries }\end{array}$ & $\begin{array}{l}\text { 1) Designate an existing directorate in each contributing sector } \\
\text { whose head (or a representative) will be a nutrition focal } \\
\text { point (to address the frequent instability of nutrition focal } \\
\text { points in the sectors) } \\
\text { 2) Strengthen the position or leadership of the Nutrition Focal } \\
\text { Point in key sectors; } \\
\text { 3) Establish a coordination mechanism for nutrition-sensitive } \\
\text { interventions in each key sector. }\end{array}$ & $\begin{array}{l}\text { 1) Existence of a multisectoral } \\
\text { national policy and a plan; } \\
\text { 2) Support of technical and financial } \\
\text { partners; } \\
\text { 3) Well-articulated nutrition policy } \\
\text { and plan }\end{array}$ \\
\hline $\begin{array}{l}\text { High demand and need for information and } \\
\text { data }\end{array}$ & $\begin{array}{l}\text { 1) Initiate thematic studies to inform decision-makers and } \\
\text { stakeholders in the field of nutrition; } \\
\text { 2) Formulate new nutrition research questions. }\end{array}$ & $\begin{array}{l}\text { Existence of data collection and } \\
\text { analysis frameworks }\end{array}$ \\
\hline $\begin{array}{l}\text { Lack of a single framework for coordination } \\
\text { and decision-making on the collection, analysis } \\
\text { and dissemination of information }\end{array}$ & $\begin{array}{l}\text { 1) Set up a mechanism for M\&E and capitalization of } \\
\text { interventions; } \\
\text { 2) Strengthen the data management system. }\end{array}$ & $\begin{array}{l}\text { The National Information on } \\
\text { Nutrition Platforms, in development }\end{array}$ \\
\hline
\end{tabular}

Despite all the efforts made by donors and international institutions to support capacity building, there is an insufficient number of experts in M\&E in the field of food security and nutrition [25].

There are cumulatively more than twenty technical departments, including those at the central and regional levels, which do not have appropriate equipment or other means of recording and monitoring data. Inadequate field collection infrastructure and modalities have been shown to be major constraints in Bangladesh, Brazil, Ethiopia, India, Peru and Zambia [7], and in the detailed development of response systems in sub-Saharan Africa [27].

Out of around thirty key technical structures at the central level, only 6 of them had a nutrition focal point, and at the level of the 74 Regional Directorates, $47.3 \%$ (i.e. 35 directorates) stated that they had a focal point. Given the training profiles of the focal points, there is therefore a need to train agents on nutrition-related topics (governance, leadership, institutional development, etc.). In addition, $48.4 \%$ of the focal points are simple agents, not occupying a particular position, which does not lend weight for consideration, internal exchange on nutrition and collaboration. In Zambia, it was found that nutritionists at the decentralized level do not have enough influence [25], playing the role of nutrition liaison officer. In addition, there is only one focal point to represent the food security sector (which is made up of several ministries (agriculture, animal and fisheries, environment, research)); there is a need to identify a focal point in each of these key ministries.

Our study revealed the existence of a diversity in the type of focal points all contributing to the improvement of coordination of activities according to the given sector; this opportunity should be seized to improve horizontal coordination in nutrition. In addition, our research indicated a plurality of typologies of data collected by the organizations at all levels. The departments in the Ministries of Education, National Solidarity and Research appeared to be the ones collecting the most types of data; this would probably be related to the cross-cutting and multifaceted nature of their activities towards their targets. However, it is not enough to just collect and analyze data: all stakeholders need to be able to use them in order to make sound decisions. Lessons from Zambia and Namibia have shown that reducing the number of variables, and therefore the number of data to be collected, improves the use of information [28].

The challenge, beyond the typologies of data collected, is to understand (or integrate) the nature of the linkages or gaps between sectors and nutrition. Stakeholders in Uganda, Kenya and Ethiopia [9] have highlighted the inadequacy of the linkages between agriculture and nutrition. In addition, the lack of technical capacity to translate the data collected into policy decisions and to plan actions poses a challenge in all sub-Saharan countries [29].

Moreover, the survey has shown a strong demand for information and data, expressed by the departments at the central level, but mainly by the 74 Regional Directorates. This strong need for information indicates the lack of data or the lack of access to data at the deconcentrated level. Gillespie and his collaborators highlighted the lack of data at the 
administrative and district level in Zambia and Odisha [25]. They identified a dependency of the departments at the regional level on the monitoring systems developed by the national or central level, which did not allow including the indicators needed at the regional or municipal level [25].

Finally, our research identified several sources or frameworks for data collection, produced and led by different ministries. This multiplicity of coordination mechanisms reflects a certain lack of complementarity in terms of planning, implementation and monitoring and evaluation. In Ethiopia, one of the highlighted findings is that the agriculture and health sectors collect their data separately, each with its own framework, and do not collaborate $[7,9]$, resulting in less information sharing [7]. In each country, different stakeholders and actors have different and competing agendas, especially in decentralized governance systems [5]. Different sectors need to be able to see the comparative advantages and reciprocity of their involvement [30].

The lack of functionality of a national nutrition $M \& E$ system to ensure monitoring, evaluation and accountability of the multisectoral approach to nutrition at country level was noted, the same observation was made in Uganda [9]. Operational linkages between the M\&E system and user institutions need to be developed for the system (multisectorality and accountability) to be successful and serve as a precursor for policy decision making [31, 32].

Our study has contributed, using the Framework for Nutrition Capacity developed by the United Nations Network for the SUN movement, to a pre-assessment of the capacities of key sectors engaged in multisectorality. This is a premiere, particularly in the implementation of nutrition operational plans in the sub-region. Using this methodology and specific evaluation criteria, we were able to provide a reflection of the situation regarding the accountability capacities of the technical service at both central and regional levels. As a result, challenges or needs were identified and key recommendations were made in order to be used in the formulation of a capacity development plan for multisectoral nutrition coordination over the next 3-5 years.

This study has some notable limitations. First and foremost, it was not intended to analyze each of the data sources or collection frameworks in detail, and to focus on the quality of the data and the indicators developed or provided. Nor did it consist in a deep analysis of the strengths and weaknesses of each information system, the modes of production, dissemination and valorization of nutrition information. Moreover, given the multiplicity of information systems, it does not claim to be exhaustive. In addition, during the course of the study, it was not possible to collect from the sectors the degrees of credibility, reliability and use of the various reports or bulletins they produce or consult; the number of respondents to this question was too small to draw conclusions on this issue. Finally, the confusion mainly between nutrition and food security data on the one hand, and social protection and food security data on the other, did not facilitate the classification of the types of data collected. At times, we reclassified the types of data collected by analyzing the indicators corresponding to the typology of data collected as reported by the respondents.

\section{Conclusion}

Our research showed a gap in the institutionalization of nutrition at the level of sectoral ministries through key structures at the central and regional level. In addition, a strong need for information and data was identified, and a lack of a single coordination and decision-making framework for the collection, analysis and dissemination of nutrition information. The needs assessed by the technical departments should serve as a precursor for the formulation of research questions in order to produce useful information and data for the sectors. Mainly, the implementation of this study among the departments enabled the staff interviewed to understand the dimensions of nutrition, and the role they have to play in the implementation of sector policy or strategy in this area. The National Information on Nutrition Platforms initiative, officially launched in January 2019, should help the country to strengthen its nutrition information system and the capacities on data analysis from key technical bodies of ministerial departments involved in the multisectoral process. These efforts will contribute to better inform decision-makers for strategic decisions to prevent malnutrition and its consequences. To this end, close collaboration and synergy of actions should be developed between the sectoral coordination bodies for nutrition, social protection and food security.

\section{Acknowledgements}

This capacity assessment in Burkina Faso was funded by Global Affairs Canada (GAC) through the REACH initiative in Burkina-Faso. We would like to express our sincere thanks to Ministry of health, Evaluation Committee, and to the Nutrition Focal Points of the Burkina Faso's nutrition UN Network. We highly appreciate the contribution of the colleagues of United Nations Network/REACH from ROME-Italy, and to Mrs Akezamutima Emelyne, Mrs Sophie Yaogo and Mrs Clarice Kabore for the finalization of this manuscript. All co-authors reviewed the first draft of the manuscript and approved its final version for submission.

\section{References}

[1] Rapport sur la nutrition mondiale. Sensibiliser pour stimuler l'action en matière de nutrition. Available from: https://globalnutritionreport.org/reports/global-nutrition-report -2018/. Accessed July 12, 2019.

[2] Food and Agriculture Organisation of the United Nations/World Health Organisation. Framework for Action. Second International Conference on Nutrition, Report ICN2 2014/3; November 19-21, 2014; Rome, Italy.

[3] International Food Policy Research Institute. Global nutrition report. Washington, DC: International Food Policy Research Institute, 2017.

[4] Heaver R. Strengthening country commitment to human development: lessons from nutrition. Washington, DC: World Bank, 2005. 
[5] Gillespie S, Haddad L, Mannar V, Nisbett N, Menon P. The Maternal and Child Nutrition Study Group. The politics of reducing malnutrition: building commitment and accelerating progress. Lancet. 2013; 382 (9891): 552-569.

[6] Baker P, Hawkes C, Wingrove K, et al. What drives political commitment for nutrition? A review and framework synthesis to inform the United Nations Decade of Action on Nutrition. BMJ Glob Health. 2018; 0: e000485. doi: 10.1136/bmjgh-2017-000485.

[7] Mejía AA, Fanzo J. Fighting Maternal and Child Malnutrition: Analysing the Political and Institutional Determinants of Delivering a National Multisectoral Response in Six Countries. Brighton, UK: Institute for Development Studies Report to the United Kingdom's Department for International Development; April 2012. Available from: https://www.ids.ac.uk/files/dmfile/DFID_ANG_Synthesis_Ap ril2012.pdf. Accessed July 11, 2018.

[8] Balarajan Y. Creating political priority for micronutrient deficiencies: a qualitative case study from Senegal. BMJ Open 2014; 4: e004784. doi: 10.1136/bmjopen-2014-004784.

[9] Hodge J, Herforth Anna, Gillespie S, Beyero M, Wagah M, Semakula R. Is There an Enabling Environment for Nutrition-Sensitive Agriculture in East Africa? Stakeholder Perspectives From Ethiopia, Kenya, and Uganda. Food Nutr Bull. 2015; 36 (4): 503-19. doi: 10.1177/0379572115611289. Epub 2015 Oct 15.

[10] Annan K. «Data can help to end malnutrition across Africa». Nature, 555: 7, 2018. Available from: https://www.nature.com/articles/d41586-018-02386-3. Accessed July 12, 2019.

[11] Ministère de la santé. Plan stratégique multisectoriel de nutrition (2020-2024). Burkina Faso; 2019.

[12] Garrett J, Natalicchio M, eds. Working Multisectorally in Nutrition: Principles, Practices, and Case Studies. Washington, DC: International Food Policy Research Institute; 2011.

[13] Jacob S, Ouvrard L. L'évaluation participative. Avantages et difficultés d'une pratique innovante. Cahiers de la performance et de l'évaluation Automne 2009, $\mathrm{n}^{\circ} 1$ ISBN 978-2-9811262-0-7 Québec; 2009.

[14] Greene JC. "Communication of Results and Utilization in Participatory Program Evaluation» Evaluation and Program Planning. 1988; 11 (4): 341-351.

[15] King JA. «Making Sense of Participatory Evaluation Practice» New Directions for Evaluation. 1998; (80): 57-67.

[16] O'Sullivan RG, Agostino A. «Promoting Evaluation through Collaboration: Findings from Community-Based Programs for Young Children and their Families» Evaluation. 2002; 8 (3): 372-387.

[17] Patton MQ. Developmental evaluation: Applying complexity concepts to enhance innovation and use. New York, NY: Guilford Press; 2011. 187 p.

[18] Alkin, MC. Evaluation roots: Tracing theorists' views and influences. Thousand Oaks, CA: Sage; 2004.

[19] Ridde V. Suggestions d'amélioration d'un cadre conceptuel de l'évaluation participative. Revue canadienne d'évaluation de programme. 2006; 21 (2): 1-23
[20] Dozois E, Langlois M, Blanchet-Cohen N. Guide du praticien de l'évaluation évolutive. Montréal, QC: La fondation de la famille J. W. McConnell et l'Institut international des droits de l'enfant et du développement; 2010. Available from: https://mcconnellfoundation.ca/wp-content/uploads/2017/07/D E-201-FR.pdf. Accessed January 10, 2019.

[21] Rey L, Brousselle A, Dedobbeleer N, Trembla MC. Les défis de l'évaluation Développementale en recherche: Une analyse d'implantation d'un Projet «hôpital promoteur de santé». The Canadian Journal of Program Evaluation. 2013; 28 (1): 1-26. ISSN 0834-1516.

[22] United Nations Network (UNN). Nutrition Capacity Assessment Guidance Package - Part I Guidance Note; 2016 a. 36 p. Available from: https://www.reachpartnership.org/documents/312104/dc7e206 6-93ab-4a8f-82c7-fba3e4d24163. Accessed April 16, 2017.

[23] United Nations Network (UNN). Nutrition Capacity Assessment. Tools and Resources Guidance Package - Part II; 2016b. 34 p. Available from: https://www.reachpartnership.org/documents/312104/aa2cbe7 9-3b4e-48c4-9bd6-3a6088554240. Accessed April 16, 2017.

[24] Food and Agriculture Organisation (FAO). Approaches to Capacity Development in Programming Processes and Tools. Module d'apprentissage 2, édition révisée. Available from: https://www.fao.org/3/a-i5243e.pdf. Accessed April 16, 2017.

[25] Gillespie S, van den Bold M; the SoC Study Team. Stories of change in nutrition: an overview. Glob Food Sec. 2017; 13: 1-11.

[26] Webb P, Ghosh S, Shrestha R, et al. Measuring Nutrition Governance: An Analysis of Commitment, Capability and Collaboration in Nepal. Food and Nutrition Bulletin. 2016; 37 (4S): S170-S182.

[27] Suresh B, Ergeneman A. A framework for evaluating food security and Nutrition monitoring systems. African Journal of Food Agriculture and Nutritional Development (AJFAND). $2005 ; 5$ (2).

[28] Eele D Indicators for food security and nutrition monitoring. Food Policy. 1994; 19: 314-32.

[29] Babu SC, Mthindi GB and D Ng'ong'ola Developing decentralized capacity for development policy analysis lessons from food security and nutrition monitoring in Malawi. African Development Review, 1996; 8: 127-145.

[30] Du Plessis LM, McLachlan MH, Drimie SE. What does an enabling environment for infant and young child nutrition look like at implementation level? Perspectives from a multi-stakeholder process in the Breede Valley Sub-District, Western Cape, South Africa. BMC Public Health. 2018; 18 (1): 240. doi: 10.1186/s12889-018-5165-7.

[31] Habicht JP Nutritional surveillance in China: results of user survey. Mimeo, Cornell Food and Nutrition Policy Program, Ithaca, New York, 1991.

[32] Report for the Second International Early Warning Conference (EWC II). Synthesis of the findings of the early warning regional consultations in Africa, Asia, the American Hemisphere and Europe. Bonn, Germany, October 16-18, 2003. 